IRSH 56 (20I I), pp. 44I-473 doi:10.1017/So0208590I I000I 98

(C) 20I I Internationaal Instituut voor Sociale Geschiedenis

\title{
Representing and Reconstructing Identities in the Postwar World: Refugees, UNRRA, and Fred Zinnemann's Film, The Search (1948)*
}

\author{
Sharif Gemie \\ University of Glamorgan
}

E-mail: sgemie@glam.ac.uk

LOUISE REES

Independent scholar

E-mail: louise8ringram@googlemail.com

Summary: This article analyses Fred Zinnemann's 1948 film, The Search, setting in the context of displaced persons in post-1945 Europe. We concentrate on Zinnemann's treatment of the United Nations Relief and Rehabilitation Administration (UNRRA), arguing that this is central to the film. We also consider the film's references to Americanism, Zionism, gender equality, and children's wartime experiences.

\section{'Everything's all right now.' \\ Mrs Murray}

At the end of World War II, the newly 'planning-minded' welfare authorities were extremely concerned about the millions of homeless people in Central Europe. ${ }^{I}$ This varied population included concentration camp survivors, forced labourers, collaborators, and prisoners of war.

\footnotetext{
* The authors would like to thank Patricia Clark, Brian Ireland, Célia Keren, Daryl Perrins, and Susanne Schrafstetter for their useful comments on earlier versions of this paper, and to acknowledge the assistance of The Leverhulme Trust.

I. On 'planning-mindedness', see Jessica Reinisch, "Introduction: Relief in the Aftermath of War", Journal of Contemporary History, 43 (2008), pp. 37I-404; see also the critique of this special issue by Sharif Gemie and Laure Humbert, "Comment: Writing History in the Aftermath of 'Relief': Some Comments on 'Relief on the Aftermath of War', Journal of Contemporary History, 44 (2009), pp. 309-318.
} 
The Allies expressed little sympathy for the supporters of the Nazi regime, but collectively designated all other homeless people as "Displaced Persons" (DPs). The Allied authorities worried about the potential dangers that they represented: epidemics, social disorder, psychological trauma, or massive cultural collapse.

Such concerns also stimulated some of the best-known and most innovative films to come out of the period. Casablanca (1942) is not only set in an exile community, but was also largely performed by a cast of European exiles temporarily based in the USA. The Captive Heart (1946), shot on location in the prisoner-of-war camp, Marlag (near Westertimke), starred Michael Redgrave as a Czech soldier who escapes from Dachau and assumes the identity of a dead British officer in order to help find his family. Both Lamprecht's Somewhere in Berlin (1946) - shot amidst the rubble of the city-and Radvanyi's It Happened in Europe (1947) depict groups of war-scarred children as figures of hope in a "new world" as they tirelessly search for shelter and food. Billy Wilder's romantic comedy A Foreign Affair (1948) is set in a grim postwar Berlin, shaped by the presence of DPs and the black market. It focuses on fraternization between US soldiers and German civilians. The action in The Third Man (1949) develops among the relief agencies and military authorities of postwar Austria.

However, one notes a common tendency for each of these films to begin their story within the context of communities of exiles, refugees or displaced persons, ${ }^{2}$ and then to turn the narrative elsewhere: to a classic love triangle in Casablanca and A Foreign Affair, to a crime story for The Third Man. ${ }^{3}$ In fact, it is hard to identify any full-length feature films which explore in depth the social and political issues raised by the massive presence of displaced persons in the post-war world: Fred Zinnemann's The Search (1948) is a significant and fascinating exception.

Why is there such a problem with the representation of refugees? The first, and most obvious, answer might be that refugees lack the ability to represent themselves: cut off from the cultural resources of their home societies, often traumatized, held in uncertain, limbo-like situations that make detailed planning for the future difficult, they seem in a poor situation to speak for themselves. In fact, following the initial shock of

2. We recognize the shortcomings of each of these terms, and in a longer work we would debate definitions, implications, and meanings. As will be seen, in this article we shall be discussing issues within the context set by UNRRA, and so will be largely accepting its definition of displaced persons.

3. This tendency is still present in more recent films: Les Egarés (2003) also begins with shots of refugees, but develops into an unusual story of the sexual passion between a dispossessed young man and a conservative young mother. One could speculate that this narrative refers, indirectly, to concerns about the growing social chasm in contemporary France between the dispossessed populations of the housing estates and mainstream society. 
displacement, exiles have often proved to be more willing and more capable of creating narratives than the bulk of the stable population: while Fred Zinnemann was planning The Search, Victor Serge was writing his Mémoires d'un révolutionnaire in Mexico, Federica Montseny was compiling her Pasión y muerte de españoles en el exilio in France, and Primo Levi had completed his memorable Se questo è un nomo in Italy. The key difference between these two forms of production is that The Search reached a surprisingly large audience, while each of the three authors cited above suffered isolation, obscurity, and exclusion during the I940s. ${ }^{4}$

The factor which prevented refugee productions from reaching a wider public was not the refugees' incapacity to express themselves competently, but the authority structures created by their new host communities. As a general rule, when refugees are accepted into other nations, they are accepted as victims, even innocent victims, of processes outside of their control. Such perceptions form an integral part of the social institutions and practices that structure their lives, and which often limit their cultures. The refugee camps of the late I940s were constructed to help refugees, but also to control and direct their activities. Often lacking adequate financial support, the relief organizations judged that the first priority of any cultural production linked to the refugees' fate was the need to appeal for public sympathy and therefore donations.

The manner in which refugees were represented was affected by some larger wartime debates. Military authorities became aware of the potential of film as a means of not just raising morale, but actually inculcating a common, patriotic military culture among the armed forces. ${ }^{5}$ The postwar civilian authorities and relief agencies followed their example: they considered it almost a duty to produce film representations of their work with refugees. There was, of course, always a constant difficulty in such productions: refugees, defined as victims, could appear as stereotypical "bad-news stories", contradicting the propaganda requirements of the agencies involved. Directors needed to ensure that this was not the case. They aimed to propagate attractive and positive images of the agencies' work, which in broad terms would convince host communities of the organizations' efficiency in dealing with such problems and would produce two reassuring messages: firstly, that the refugees were not a threat to social stability, and secondly, that the host community was moral and generous.

During this period a number of imaginative directors faced these problems and produced some innovative and striking short documentaries to illustrate the refugees' experiences. Modern Orphans of the Storm (1939)

4. On the initial reception of the work of Primo Levi, see Manuela Consonni, "The Written Memoir: Italy, 1945-47", in D. Bankier (ed.), The Jews Are Coming Back (New York [etc.], 2005), pp. I69-185.

5. Benjamin L. Alpers, “This is the Army: Imagining a Democratic Military in World War II", in Gordon Martel (ed.), The World War Two Reader (New York [etc.], 2004), pp. I45-179. 
is one such example. Produced on behalf of British National Joint Committee for Spanish Relief, the film features the committee's chairperson - the Duchess of Atholl - and focuses on the plight of refugee Basque children in Britain, placing them at the centre of the story as the "saved" ones. Uniquely positive in tone, Modern Orphans of the Storm depicts the refugee children as happy, healthy, grateful recipients of foreign aid. It is not until the end of the film that the Duchess informs the audience that the vital work in refugee camps can only be maintained through the "continued sympathy and support of the British people". The soundtrack of refugee children singing folk songs was also sold in aid of the Relief Fund: a forward-thinking fundraising device which is still used in appeals today.

In contrast, both Seeds of Destiny (US Signal Corps Photographic Centre, 1946) and The Pale Horseman (US Information Service, I947) are bleaker in tone, concentrating again on the plight of children, but in the context of starvation, disease, and suffering. Depicted as innocent victims, graphic shots of traumatized, sickly, and malnourished children are shown with the intention of shocking audiences into donating generously to relief appeals. Seeds of Destiny - sponsored by the United Nations Relief and Rehabilitation Administration (UNRRA) - is credited with raising over US\$2 million for war relief programmes. It was shown across the USA in cinemas, town halls, and at village meetings, and won Best Documentary Short Subject prize at the 1947 Academy Awards. ${ }^{6}$ DPs also feature as wandering masses in the British documentaries $A$ Defeated People (Crown Film Unit, 1946) and Children of the Ruins (Crown Film Unit, 1947) which describes their journey as "the whole world on the move". These innovative documentaries, while not as well-remembered as their fictional counterparts, are important examples of the application of realist techniques to film-making.

These documentaries suggested that relief was vital in assisting the immediate needs of displaced persons, but also that it should only be provided on a temporary basis. They promoted the Allies' preferred policy as the ideal solution: "re-placing" the displaced persons in their home countries and thus reuniting them with their families. Clear borders needed to be drawn between displaced persons, and European and American states. This wave of documentaries also publicized the work of aid agencies such as UNRRA and the Red Cross, showing them playing vital roles in rehabilitating displaced persons and so contributing to the long-term process of the social reconstruction of Europe. They show displaced persons almost always as innocents: wretched, traumatized

6. Source: InternetArchive.org at page http://www.archive.org/details/SeedsofDestiny; accessed 25 March 20I0. 
people, unable to help themselves. Rather than depicting these people overcoming their experiences through their own initiatives to recreate communities, possibly assisted by UNRRA and others, the tendency is to highlight the various roles of welfare organizations, championing their selfless work and remarkable results. ${ }^{7}$ Whilst images of displaced persons may dominate these documentaries, their individual experiences are secondary to the promotion of the aid agencies dealing with the mass of hopeless souls wandering aimlessly across Europe. ${ }^{8}$

In this context, The Search represents an important initiative: it was a feature-length film, backed by the resources of a major Hollywood studio (MGM) that focused on the experiences of refugees and the process of rescue and rehabilitation. It was an innovative film, consciously imitating two of the newest forms of film-making.

Firstly, despite being fictional, The Search deployed similar techniques to those used in documentaries of the time, such as the inclusion of a voiceover and the use of spoken foreign languages without subtitles. Secondly, like many other directors of the immediate postwar years, Zinnemann was impressed by the techniques pioneered in the new wave of neo-realist films: he cites Rossellini's Rome: Open City (1945), De Sica's Shoe Shine (1946), and Lindtberg's The Last Chance (1945) as inspirations which he consciously sought to emulate. These films were marked by dark political and social overtones, and reflected on the desperation and poverty felt in the post-World-War-II world. Typically films from the genre are set amongst the poor and working class, and usually filmed "on location" using non-professional actors and in a documentary style. Important social issues are usually at the heart of their narratives, and they often feature children in central roles. ${ }^{9}$ Zinnemann saw these

7. On the initiatives taken by refugees themselves, see Lucienne Domergue, "La presse espagnole de l'exil à Toulouse et dans le midi de la France", in her edited collection L'Exil Républicain (Toulouse, 1999), pp. 207-224; and L. Domergue and M. Laffranque, "Les espagnols exilés à Toulouse et la culture: l'exemple des libertaires", also in L'Exil Républicain, pp. 19I-206; Vicente Llorens, Estudios y Ensayos sobre el exilio republicano de 1939 (Seville, 2006), pp. I $29-136$.

8. The idea of DPs as a wandering mass is used throughout $A$ Defeated People (Crown Film Unit, 1946). The documentary is equally negative about DPs as about German civilians who the voiceover enthusiastically describes as having eyes "like dead rabbits".

9. Neo-realist films are often described in terms of "film consciousness", with directors from the genre motivated by the impact on the viewer of viewing lives represented in film. The greatest single influence on directors such as Rossellini and De Sica was the mood of antifascism that marked the period immediately following the end of World War II. They wanted to highlight the impact of the war on the everyday lives of ordinary people. For a further discussion on the Italian neo-realist movement, please see L. Ucnik, "Aesthetics or Ethics? Italian Neorealism and the Czechoslovak New Wave Cinema”, in L.E. Ruberto and K.M. Wilson (eds), Italian Neorealism and Global Cinema (Detroit, MI, 2007), pp. 54-72. 
films as important innovations for they used "the raw material of contemporary history in order to make a dramatic document". ${ }^{\mathrm{IO}}$

Zinnemann aimed to address an important social issue in a form which would reach a popular audience. For him, The Search had a mass-educational aspiration. It had a budget of some US\$250,000 (which could be compared to Casablanca's estimated US\$I,039,000): ${ }^{I}$ not a colossal budget, but certainly generous enough for Zinnemann to be able to afford experienced, professional actors, to stage crowd scenes, to employ a capable camera team, to commission a sound-track, to take extensive external shots in ruined German cities, and to hire plentiful trucks and equipment. The Search certainly looks like a more professional and more polished product than its near-contemporary, Rossellini's Germany: Year Zero. The one constraint that Zinnemann faced was a limited amount of film, which was scarce in postwar Europe: this meant that retakes had to be kept to an absolute minimum. ${ }^{22}$

At first sight, the points we have rehearsed might well sound like the recipe for an obscure, awkward representation of minority lives: a difficult subject, whose representation was over-determined by powerful authorities, flushed with the confidence of victory; a relatively unknown director; and an audience tired of the drab misery of the war years and thirsty for escapism and glamour. Here, there is a quite astonishing surprise: in 1948, The Search was a hit. It won a series of prestigious awards: an Oscar for Best Writing (and nominations for three more); a Special Juvenile Award for Ivan Jandl - the film's child star; the BAFTA UN award; and three Golden Globes: for Best Film Promoting International Understanding, Best Screenplay, and a second juvenile award for Jandl. ${ }^{13}$ It was celebrated in American reviews as "an absorbing and gratifying emotional drama of the highest sort", and a "major revelation in our times". ${ }^{14}$ The Search was given a full two-page spread in Life magazine and won a place in both Time magazine's and the National Board of Review's top ten films of $1948 .^{\text {Is }}$

Iо. Fred Zinnemann, "Different Perspective", in Richard Koszarski (ed.), Hollywood Directors, 1941-1976 (Oxford, 1977), pp.I44-I47, I44, originally published in Sight and Sound (Fall, 1948). I I. J.C. Robertson, The Casablanca Man: The Cinema of Michael Curtiz (London, 1993), p. 79. I2. J.R. Silke, "Zinnemann Talks Back", in G. Miller (ed.), Fred Zinnemann Interviews (Jackson, MI, 2005), pp. 9-26, I9.

I3. Source Internet Movie Database at page http://www.imdb.com/title/tto040765/.

I4. Movie review of The Search by Bosley Crowther of The New York Times published 24 March 1948, The New York Times Online, at http://movies.nytimes.com/movie/review?

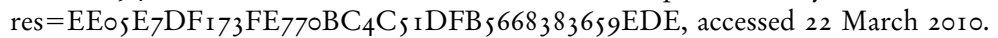

I5. See the full article from Life dated s April 1948, at http://books.google.com/books? $\mathrm{id}=$ ZEEEAAAAMBAJ\&pg $=$ PA75\&dq $=$ the + search\&as_pt $=$ MAGAZINES\&cd $=\mathrm{I} \# \mathrm{v}=$ onepage $\& \mathrm{q}=$ the $\% 20$ search\&f=false and the article "Cinema: The Best of 1948 " at Time Online at page http://www.time.com/time/magazine/article/o,9171,79965 I,00.html. 
The film was also a success when released in Britain at the end of I949, receiving a Royal Premiere attended by Queen Mary, and gaining positive reviews in numerous newspapers and film journals such as Sight and Sound, The Daily Mail, The Star, and The Evening Standard. ${ }^{16}$ Not all British reviews were favourable: Paul Holt of The Herald described the film as "intolerably saccharine and coy". ${ }^{17}$ But the majority opinion was clearly positive. One reviewer for The Times commented that the film was "a terrifying reminder of [...] war and Fascism", and concluding that it was "a powerful plea for peace". ${ }^{18}$ The Neres of the World also noted the effectiveness of filming on location, adding "take a careful look at Germany's air-raid ruins and then thank your lucky stars that the RAF were on our side". ${ }^{19}$ The Search's clear commercial success is another good reason for studying it: through analysing this successful, popular film, we can better understand how public opinion in the USA, but also to a lesser extent in Europe, may have conceptualized the issues represented by DPs.

While Zinnemann had made a number of low-budget films before I948, The Search proved to be his big break. He went on to a successful career directing twenty-two feature films - including High Noon (1952), From Here to Eternity (1953), and The Day of the Jackal (1973) - plus eighteen shorts and a documentary. He won four Academy Awards and was nominated for Best Director a further five times. ${ }^{20}$ The male lead of The Search, Montgomery Clift, became a successful actor, starring in films such as From Here to Eternity and Raintree County (Dmytryk, 1957). ${ }^{21}$ Aline MacMahon, the film's female lead, continued to star in small film roles until the late i950s when she retired and concentrated on theatre work. ${ }^{22}$ The child star of The Search, Ivan Jandl, enjoyed less success, starring in three minor Czech films, then working briefly in radio and as a theatre stage manager. He died at the age of fifty of diabetic complications. ${ }^{23}$

What exactly is the subject of Zinnemann's film? This is a surprisingly difficult question to answer: a pointer to the film's originality. For Lawrence Baron, it is an American Holocaust film, one of seven produced

16. Information contained in the MGM Press Book published in Britain in 1949; British Film Institute archive.

17. Paul Holt's review of The Search, The Herald, 28 October 1949.

18. Review of The Search, The Times, 29 October 1949, author unknown.

19. Review of The Search, The News of the World, 30 October 1949, author unknown.

20. Miller, Fred Zinnemann Interviews, p. vi.

2I. See notes on Montgomery Clift's career at Internet Movie Database at page http:// www.imdb.com/name/nmo001050/bio, accessed 25 March 2010.

22. See Aline MacMahon's career at http://www.answers.com/topic/aline-macmahon, accessed 25 March 2010.

23. See Ivan Jandl's mini-biography at Internet Movie Database http://www.imdb.com/name/ nmo417389/bio, accessed 25 March 2010. 
in the USA between 1945 and $1959 .{ }^{24}$ According to Brian Etheridge, it is a proto-Cold-War film, significant for demonstrating Zinnemann's slide from a wartime leftism to a more establishment liberalism. ${ }^{25}$ Both these interpretations are legitimate but - arguably - each sidelines key elements of the film. The point that strikes us is the prominence that Zinnemann gives to UNRRA. (Readers who are not familiar with this organization are advised to consult the appendix below.) To our knowledge, this is the only featurelength film from the I940s that takes the work of UNRRA as central to its dramatic narrative: a second good reason for studying the film.

In the sections that follow, we shall analyse The Search as a contribution to refugee history: our primary concern is the film's approach to the rehabilitative role of the USA in postwar Europe and - in particular - the role of UNRRA. We shall approach these themes in two ways. Firstly, as this is a film with documentary pretensions, aiming to combat the American public's "lack of comprehension of the extent of suffering abroad", ${ }^{26}$ we shall consider the extent to which it can be seen as an accurate representation of relief in postwar Germany. Secondly, we shall consider the lesson it taught its audience concerning the American presence in Germany. Several key scenes will be discussed in detail and the overall style and tone of the film will be assessed and placed in the wider context of postwar representations of refugees. ${ }^{27}$

\section{FINDING THE SEARCH}

The film has an unusual plot. It is based on two simple themes: a lost child looking for his mother, and his mother's search for him. This plot means that the film works as a Hollywood "weepy", ending with a carefully constructed reunion of mother and child. It presents the classic, formulaic Hollywood narrative of cause and effect in which a problem is introduced and, as the film progresses, characters work through this problem until a solution is found. In The Search the problem is clearly the lost child, searching for his identity, and ultimately rediscovering himself and finding

24. Lawrence Baron, “The First Wave of American 'Holocaust' Films, 1945-1959”, American Historical Review, i Is (2010), pp. 90-II4.

25. Brian C. Etheridge, "In Search of Germans: Contested Germany in the Production of The Search", Journal of Popular Film \& Television (2006), at http://news.movieretriever./com/articleIGI-I $1055458 /$ search-germans-contested-germany.html, accessed I9 February 2010.

26. Zinnemann, "Different Perspective", p. I45.

27. When analysing key scenes from films the technique of "reading" film is utilized. James Monaco states that film is like a language communicating meaning through its mise-en-scène, or constructed elements of a shot, including lighting, camera angle, gesture, and body language. He suggests that in analysing the connotative meaning, alternative meaning can be drawn from key scenes. This article will utilize parts of this technique. His formula for the "reading" technique is outlined in James Monaco, How To Read a Film (Oxford, 2000). 
his mother. The main characters function as "problem-solvers" who not only assist Karel on his journey, but work through the larger, ongoing theme of rehabilitating Germany.

As Karel Malik - the lost Czech child - looks for his mother, he encounters a series of characters. The most prominent of these are Mrs D. Murray (her first name is never revealed), who is the Director of an UNRRA team based in Germany, and "Steve" (actually Ralph Stevenson), an American military engineer based in postwar Germany. Karel is central to the narrative, and is present in most of the scenes. The three adults - Mrs Murray, Steve, and Karel's mother, Mrs Malik - each "search" for Karel. While Mrs Murray and Mrs Malik both work in the UNRRA camp, there is surprisingly little interaction between the three adults: their three stories form largely independent subplots. It is only in the last scene that all three adults and Karel are present in the same place, and even here they are never shown together in the same shot. Karel is therefore required to carry the weight of the narrative and, if there is a structural flaw to the film, it lies here: while Jandl, only nine years old, presents a praiseworthy and engaging performance, there are a few clumsy, awkward moments, and some unalloyed, coy, sentimentality, such as the moment when Karel recalls his lost parents: "Steve, what does that mean: 'mother'?" (I.08). ${ }^{28}$

The plot is complicated by the addition of other features. There is the introduction and unmasking of a "false Karel": a Jewish boy (Joel Markowsky, played by Leopold Borkowski), who out of fear adopts Karel's Czech identity. Quasi-parental links are developed and then unravelled - firstly and briefly - between Karel and Mrs Murray, and then - at greater length - between Karel and Steve. A still greater level of complexity is introduced by the recurring device of failed journeys: Karel runs away from an UNRRA camp near the beginning of the film, only to return to it at the end, and also runs away from Steve, only to return to his house; Steve plans to return to the USA, but then cancels his journey due to his growing affection for Karel; Mrs Malik helps in the UNRRA camp, plans to leave to continue looking for her lost son elsewhere, but decides at the last minute to return, just in time to find her son and to produce the climatic happy ending. The one stable, non-travelling person in the film is Mrs Murray.

One final, unusual, feature of the film is the complete absence of any romantic interest: like the innovative neo-realist directors, Zinnemann's priorities are elsewhere. The single, strongest emotional bond is that of mother and child; Steve and Mrs Murray are both present in the narrative

28. Zinnemann later explained how he found it difficult to overcome Jandl's own "emotional block". He employed a coach to help him learn his lines by rote as Jandl was unable to speak English. This could have contributed to the slight clumsiness in some of Jandl's scenes; F. Zinnemann, A Life in The Movies (New York, 1992), p. 69. 
only as substitutes for authentic mother love. Despite its clear central theme (a child looking for his mother) the structure of the film is intricate and knotty, and it seems likely that MGM executives considered that it would be a demanding film for audiences. They decided - against Zinnemann's wishes - to add a voiceover (probably by Aline MacMahon) during the opening scenes. ${ }^{29}$ Some critics disliked this, with one reviewer for Montbly Film Bulletin commenting that, "the opening scenes [...were] spoilt by an intrusive and tiresome commentary". ${ }^{\circ}$

Zinnemann was proud of his extensive research concerning conditions among displaced persons, and radically revised his original script after travelling through Germany and consulting with UNRRA personnel. ${ }^{3 \mathrm{I}}$ The Search was - in part - intended to provide an accurate portrayal of UNRRA's working methods: the film was largely shot on location in the American Zone of Germany; the UNRRA uniforms are accurate copies; UNRRA screening procedures form an important element of the plot; and incidents in the film are based on real-life accounts. Even the co-option of Mrs Malik as a camp worker illustrates UNRRA's policy of recruiting DPs as helpers. Aline MacMahon and Montgomery Clift both spent days living in, respectively, an UNRRA camp and among US Army engineers before the film. ${ }^{32}$ UNRRA certainly assisted Zinnemann in making the film, and looked forward to its completion. "We are so used to knocks that a word of commendation once in a while comes almost as a shock", one grateful UNRRA official wrote to Zinnemann. ${ }^{33}$

Susan Pettiss, an American UNRRA employee working in Munich, was assigned the task of accompanying Zinnemann and his team on research trips to children's centres. She recalls driving through bombedout towns to find locations for filming. Every now and then, "someone would yell out, 'Hold it, wonderful ruins' and the car would stop and someone would start shooting film". ${ }^{34}$ There is evidence to suggest that UNRRA employees were pleased with the final result. Pettiss, for example, was impressed with the film's realistic, honest portrayal: "I was relieved [that it was not over-dramatized], moved; and on leaving the

29. G. Phillips, "Fred Zinnemann talking to Gene Phillips, 1973", in Miller, Fred Zinnemann Interviews, p. 43. In this period, voiceovers were normally spoken by men.

30. P.H., Review of The Search, Monthly Film Bulletin, November 1949, p. 195; also Sight and Sound, January I950, p. 2 I which describes the commentary as "distracting".

3I. Etheridge, "In Search of Germans" discusses this point at some length.

32. Aline MacMahon actually shadowed one of UNRRA's female directors who Zinnemann used to form the general pattern for MacMahon's screen role: see the MGM Press Book released in Britain in 1949; BFI Archive.

33. UNRRA Archives (New York), S-0425-0036-10, Williams H. Wells to Zinnemann, 4 March 1947.

34. Susan T. Pettiss and Lynne Taylor, After the Shooting Stopped: The Story of an UNRRA Welfare Worker in Germany 1945-1947 (Crewe, 2004), p. 202. 
[cinema] I had to walk fast in the cold darkness of the street to get hold of my emotions." " However, the extent to which The Search can be seen as an "authorized" depiction of UNRRA at work remains open to question.

Certainly, the film provides many vivid images of postwar Germany. The first shots set the tone: the viewer can see that we are in a large, partly wrecked building, but it requires a few moments to work out that this is a railway station. Mrs Murray walks in, holding a flashlight, leading an UNRRA team meeting a new contingent of DP children. Later, the film features extended journeys by truck through the grim, devastated cityscapes of postwar Germany. (Clift was struck by these sights. Commenting on his arrival in Germany, he said, "I didn't know it was a town until someone said, 'This is Munich'. It was a ghost city [...] something you can't describe." ${ }^{36}$ ) Elsewhere, there are shots of a large, four-storey German army barracks which has been converted into an UNRRA camp.

Steve's location is quite different: he lives in a requisitioned house. This is (or was) a middle-class home, replete with fussy interior decoration, mantelpieces, skirting-boards, and framed pictures on the walls. The contrast between his lifestyle and that of Mrs Murray (usually pictured in the UNRRA camp) is one of the most striking themes of the film. In shots reminiscent of the documentaries of DPs, The Search also made use of child DPs for a series of effective crowd scenes: again, the viewer can easily see the contrast between the stunned, frightened, near-mute children of the opening scenes and the well-dressed, upright, energetic children, full of life, scrambling to pick up their rucksacks in the last scene. The film's ending suggests a cycle of relief work: as the "rehabilitated" children leave, Mrs Murray prepares to meet a new group of youngsters who are in "particularly bad shape" (I.28).

One other dimension is integral to the film. In the first scene featuring a crowd of children, Zinnemann stresses their variety: they come from different countries, they have different stories of evasion and imprisonment, and they speak a bewildering variety of languages. These points suggest the widereaching effects of Nazism and the vast scale of the issue posed by DPs, and echo impressions recorded by relief workers. ${ }^{37}$

By the last scene of The Search, however, the crowd of children are identified as Jewish: they are addressed in Hebrew by two adults, they

35. Ibid., footnote to p. 202.

36. MGM Press Book, 1949.

37. Taha Zahra estimates that in September 1945 UNRRA was responsible for over 6 million DPs in Europe; there remained a further 7 million allied DPs in the Soviet zones of Germany and Austria, and I $2-13_{3}$ million Germans who had either fled or were expelled from eastern Europe. See Taha Zahra, "Lost Children: Displacement, Family, and Nation in Postwar Europe", Journal of Modern History, 8 I (2009), pp. 45-86, 45. 


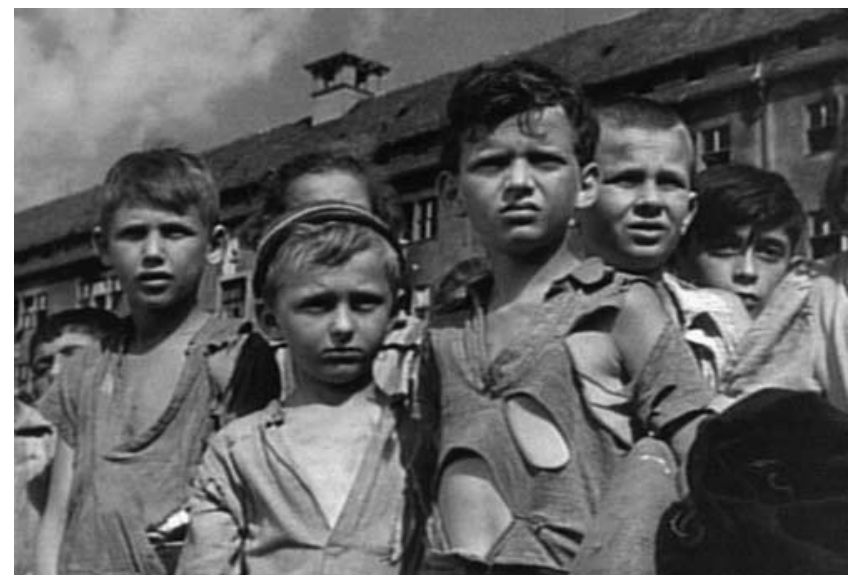

Figure I. The children of The Search: "Karel" is the smaller of the two boys in the centre, wearing a cap. In the background is an old German army barracks which has been converted into an UNRRA camp.

Warner Bros. Used with permission.

shout "Shalom!" enthusiastically to the UNRRA workers, the room in which they gather is decorated with Hebrew slogans and the Star of David, and we are told that they are leaving for Palestine. The UNRRA camp has been converted into a processing centre solely for Jewish children. Karel's story seems to run parallel with theirs: his Czech family had been picked up by German police, he had been sent to Auschwitz (and bears a numbered tattoo on his left forearm), and he happily mingles with these young Jewish travellers. It is not until mid-way into the film that we are given a vital point of clarification: in a single sentence, Mrs Murray identifies the Maliks as non-Jewish, but one wonders, amidst this complex, rambling plot whether viewers would have grasped the significance of this statement. ${ }^{3}$ We will return to Zinnemann's treatment of Jewish identity and the Holocaust below.

If there is a single, unifying theme to the movie, it is the idea of putting people back into their places. The substitute parenthood offered by Steve and Mrs Murray to Karel is rejected; the "false Karel" is identified and led back to his true location (with the other Jewish children); the real mother and the real son are reunited: they return to Czechoslovakia; the Jewish children "return" to Palestine; the American Steve will return, without an adopted son, to the USA; and Mrs Murray - here, there remains a question. Where was her true place? We will go back to Mrs Murray, after considering the wider context in which the film was produced. 


\section{THE SEARCH: PROMOTING THE “AMERICAN CRUSADE"?}

The United States was more fortunate than most other nations during the war. American soldiers fought overseas and after Pearl Harbour no fighting took place on US territory. Not only did the country experience less physical devastation, American society may well have emerged with a greater confidence in itself. Alan Brinkley observes that the American experience during the war radically enhanced belief in American ideals, giving them a new "crusading" quality. Americans could consider themselves as an effective moral force in an immoral world, and they could also believe that their commitment to freedom and justice would serve as a model for all other nations. ${ }^{39}$ Their experiences in diverse occupied and liberated countries confirmed such ideas. ${ }^{4}$

Ira Hirschmann, an American businessman who worked for UNRRA, observed that "The [British] spirit was polite, dry, well routinized and inflexible as compared with the American jovial, happy-go-lucky, spontaneous informality." ${ }^{4}$ The Search neatly illustrates this moment of American self-confidence: we see Steve explaining to Karel about the "Liberty Bell" - a symbol synonymous with American justice and freedom - and teaching him about Lincoln, the President associated with freeing slaves at the end of the Civil War.

Following the end of World War II, in a bid to promote "Americanism", Washington employed all available tools of public and cultural diplomacy to influence the hearts and minds of Europeans, and as a result American "pop culture" spread throughout Europe with a new intensity during the late I940s and early I950s. Rob Kroes even suggests that it was America and American culture that helped Europeans to find a common identity in a disrupted postwar world. ${ }^{42}$ It is certainly true that postwar Europe was marked by a prominent American influence in television, cinema, music, popular literature, education, and even in political campaigning styles. Some European commentators, however, were concerned about the effects of modernization and the rise of "mass culture". ${ }^{3}$

39. Alan Brinkley, "World War II and American Liberalism", in L.A. Erenburg, and S.E. Hirsch (eds), The War in American Culture: Society and Consciousness during World War II (Chicago, IL [etc.], 1996), pp. 313-330, 322-324.

40. Andrew Buchanan, “'Good Morning, Pupil!': American Representations of Italianness and the Occupation of Italy, I943-45”, Journal of Contemporary History, 43 (2008), pp. 21 7-240. 4I. Ira A. Hirschmann, The Embers Still Burn: An Eye-Witness View of the Postwar Ferment in Europe and the Middle East and Our Disastrous Get-Soft-With-Germany Policy (New York, 1949), p. I 20.

42. Cited in A. Stephan, The Americanization of Europe: Culture, Diplomacy and AntiAmericanism after 1945 (New York, 2008), pp. I-2.

43. Ibid., p. 23. 
The twentieth-century European left disliked the capitalist dynamics of the USA, whilst the right aligned America with a challenge to traditional hierarchies and a refusal to defer to constituted authority. ${ }^{44}$

American influences were growing stronger. In the first half of 1946, 38 American films were released in France; in the same period in 1947 , there were 338. Over the next decade, half the films released in France were American, and these were seen by 43 per cent of the viewing public. ${ }^{45}$ Following its military defeat, the Federal Republic of Germany was occupied by, and remained dependant on, the US for half a century. Hundreds of thousands of GIs brought the German population into direct contact with American culture and American influences were felt across the country in libraries, universities, publishing houses, and radio stations. Stephan suggests that for Germany - its history discredited, its culture distorted, and its language contaminated by Nazism - Americanization became a replacement for its lost identity. ${ }^{46}$ In The Search this image of America as a "cultural saviour" is illustrated through Steve and his swing music, pin-up girls, and the fact that he teaches Karel English using American magazines. One 1949 review of The Search noted this themes, describing its depiction of Americanization constituting victory over evil as "a comforting fable" for audiences. ${ }^{47}$

Groups of American cultural officers were given the task of reconstructing cultural life in Germany in spring I945. They sought to influence every section of the media, intellectuals, and elites. So far-reaching was this paternalistic control that American censors refused to allow Zinnemann's earlier film The Seventh Cross (1944) - which depicts Nazi ideals and concentration camps - to be seen in Germany, for its representations of protest against state power might have supplied Germans with arguments against the occupying forces. ${ }^{48}$ In this context, the absence of German characters in The Search becomes comprehensible: the film shows America assisting Europe while the German people remain quietly in the background. We meet Czechs, Poles, French children, British people, and Americans, but there is not a single word spoken by a German character throughout the film. In two of the external shots, we see people walking along a street and standing on a bridge, and we can

44. B. O'Connor, Anti-Americanism: History, Causes, Themes (Oxford, 2007), p. I90. See also Jessica C.E. Gienow-Hecht, "Always Blame the Americans: Anti-Americanism in the Twentieth Century", American Historical Review, i I I (2006), pp. 1067-1091, and Seth D. Armus, "The Eternal Enemy: Emmanuel Mounier's Esprit and French Anti-Americanism", French Historical Studies, 24 (200I), pp. 271-304.

45. Stephan, Americanization of Europe, p. 54.

46. Ibid., pp. 9, 70 .

47. Monthly Film Bulletin, November 1949, p. 195.

48. Stephan, Americanization of Europe, p. 73. 
guess that these might be Germans. Another brief shot shows an elderly woman and two children - presumably German - living in the rubble. Karel, when escaping from Steve, passes them by with only a moment's pause, suggesting that he will not look back to the "old" Germany for answers, but keep moving towards a new world. These brief glimpses of German characters suggest how firmly the film is focused on the far more active American leading characters.

This is zero point, and the opportunity for Europeans to become more "international", more American. O'Connor dismisses the idea of an "American crusade" in Europe, claiming that America's gains and increased global domination were a result of the collapse of world order during and after the end of World War II rather than a result of intentional US policy to promote Americanism..$^{49}$ In fact, The Search suggests something similar: it places a very "American" UNRRA at the centre of a chaotic world and utilizes the strong, efficient character of Mrs Murray and the likeable, comedic, easy-going character of Steve to promote the US as a stabilizing, directional, and trustworthy force in a disrupted world. Towards the end of the film Mrs Murray, the American, takes the arm of Mrs Malik, the European: their bond is formed and sealed with Mrs Murray's words, "everything's all right now" (I.37).

\section{MRS MURRAY AND “STEVE”: A STRANGE}

INTERNATIONALISM AND A BENEVOLENT AMERICA

The film develops in two starkly contrasting environments: the UNRRA camp and the requisitioned home, each represented by a different lead actor suggesting a different aspect of American power: Mrs Murray and Steve. The UNRRA scenes are usually crowd scenes: they feature dozens of children, teams of UNRRA officials working together in offices, large buildings, and some external shots. These are the elements which would have eaten up Zinnemann's budget. On the other hand, the American military presence in Germany is stripped down to two soldiers living in a reasonably large house, with only a few external shots. (Elsewhere we see a jeep, one shot of the military police, and a sentry post outside the UNRRA camp.) To some extent, the visual disparity between the two locations may have been dictated by budget constraints, but the different weight given to them points to the film's centre of gravity. Zinnemann needed to explain and explore the unfamiliar UNRRA camp for his audience; he could reasonably assume that his viewers considered that they knew what American soldiers were like, and therefore the military presence could be reduced to mere shorthand. 
The first thirty minutes of the film unfold within the context set by UNRRA. This is often a bewildering world, but Mrs Murray is clearly in command and she acts as a confident and trustworthy guide. Her orders open and close the film, from: "Get them out as quickly as you can, but be careful with them, they've had a very rough trip" (2) to a near-imperious "Mr Stevenson!" (I.38) as she waves to Steve, telling him to direct Karel to his mother. We hear a mixture of languages: English, French, German, Polish, Czech, and Hebrew, with no subtitles. ${ }^{50}$ The awkward situation of relying on a translator is thus reproduced in the film.

Although children are constantly involved, this is also a formal, bureaucratic world. The UNRRA workers sit at desks, with large phones in the foreground of the shots. Pens, rubber stamps, blotting pads, and boxes of filing cards lie in front of them, folders line the shelves behind them. "Let's make this as exact as we can", Mrs Murray tells Mrs Malik (45). In this world, there are no couples or domestic scenes: when the UNRRA characters go outside they usually travel in trucks. We never learn Mrs Murray's first name, and she speaks formal English throughout the film. Alone of all the characters in the film, she consistently addresses the Montgomery Clift character as "Mr Stevenson", not "Steve".

Steve's world, on the other hand, is reassuringly familiar. While set in a requisitioned house in Germany, this is a recognizably American middle-class domesticity, with a drinks cabinet, swing music on the radio, a goldfish bowl, and a dinner gong. Steve is a near-perfect embodiment of the all-American boy, first seen lounging back in his jeep and accomplishing the astonishing feat of making an American army uniform look (almost) sexy. English is the predominant language in his scenes: while brief phrases are spoken in French, German, and Italian, these are merely for comic effect. "You can use English all over the world", Steve cheerfully informs Karel (55). His English, however, is folksy and informal: one of Steve's first lines is "Holy Moses!" (42). "You wouldn't be holding out on me, would you?", he asks Karel, "I gotta find out sump'n about you" (48). His colleague, Jerry Fisher, addresses him constantly by his nickname.

One gets some strange premonitions watching them together: their easy, relaxed authority, their confidence in recreating American domesticity in this strange land, their friendly informality all look forward to the celebrated crew of The Enterprise and a string of "buddy" movies. Such scenes provide an effective illustration of a new, American, interpretation of internationalism, in which the easy, comfortable authority of American 
military personnel is self-evidently superior to the shattered cultures of Europe. ${ }^{\text {I }}$

The relationship between Steve and Karel can be read as an illustration of the dilemmas of American postwar foreign policy, and as a lesson in the need to maintain clear borders between the USA and the rest of the world. Steve aims to adopt Karel and then to take him to America, but his plans become unnecessary when Karel and his mother are reunited. In this manner The Search deflates one deep-rooted American fear: the spectre of a new wave of huddled masses leaving a shattered Europe for the USA, and bringing with them all the problems of the old continent: its political extremism, poverty, and disease..$^{2}$ Steve's superior, Jerry, comments that if the correct administrative procedures were not in place, "we'd have all of Europe in America" (I.00). Reuniting and repatriating DPs, not migration to the USA, is shown in The Search as the correct solution to Europe's problems. ${ }^{53}$

At first sight, Steve would seem to win easily any popularity contest with Mrs Murray. He is on screen for about forty minutes, she for about twenty. But some odd features emerge as one compares them. Steve is impetuous: frustrated by rules and regulations, contemptuous of red tape. Ten years after The Search, Eddie Cochrane sneered "Who cares?", when reminded that his folks would be coming home soon; we could almost imagine the same words on Steve's lips. While Mrs Murray wants to process Karel correctly, following UNRRA's procedures, Steve wants to adopt him. While Mrs Murray works for a rehabilitation agency, it is Steve who actually rehabilitates Karel: he tends Karel's feet, clothes him, feeds him, teaches him English, and presents him to company. By the last scene, however, Steve appears as a curiously unsuccessful character. $\mathrm{He}$ fails to outwit the immigration rules, he fails to adopt a child, and we never see a single bridge that he has rebuilt.

While Mrs Murray is on screen less than Steve, the scenes featuring UNRRA workers and offices last for about forty-five minutes: slightly

5I. It is interesting that whilst Zinnemann chooses to concentrate on the psychological effects of war in The Search, he moves to depict the physical effects of the war on the "indestructible" American GIs in his later film, The Men (1950), which stars Marlon Brando as a World War II veteran coming to terms with losing the use of his legs.

52. Concern that Nazism was synonymous with Germans was evident across America. In his New York Post columns, Orson Welles was openly critical of the American relief effort in Germany and the reforms taking place in postwar Europe. He stated that rehabilitation, "would not eradicate the spectre of Fascism" - an idea he also discusses in his film The Stranger (1946) in which he plays Kindler, a notorious Nazi who has adopted an American identity and married the daughter of a Supreme Court justice. For a full discussion of this film, see C. Higham, The Films of Orson Welles (London, 1974), pp. I00-1 10.

53. In fact, American policy did change in June 1948 , when the DP Act was passed, and some substantial (but controlled) immigration was permitted. See Roger Daniels, Coming to America: A History of Immigration and Ethnicity in America Life (New York, I99I), pp. 328-332. 
longer that the scenes featuring Steve and Jerry. She interviews all the film's main characters at her desk: on each occasion she gives them accurate advice, shrewdly estimating that Karel needs "rest and confidence" (I 2), telling Mrs Malik not to give up hope of finding her son, and refusing to offer any special privileges to Steve. On screen, Steve's slim, wiry body looks smaller than Mrs Murray's substantial curves. Their contrasting roles almost suggest that gender identities have been reversed in the film: he is the good-looking, flighty, over-emotional, caring, irrational character while she represents the plain but reliable voice of authority.

The contrast between the two presents an odd, misleading, picture of American authority in post-war Germany. Let us contextualize Zinnemann's treatment of UNRRA.

At first, one is struck by the choice to represent UNRRA as female, and by the strong female presence throughout The Search: two of its lead characters are women - Mrs Murray and Mrs Malik - and it is a woman's voice who speaks the voiceover during the first third of the film. This represents an imaginative decision by Zinnemann: it is noteworthy that, for example, the near-contemporary documentary, Seeds of Destiny (1946), while giving prominent place to UNRRA's work, does not foreground the work of women in any comparable manner. On the other hand, this prominent female presence certainly corresponds to some contemporary images. Francesca Wilson, an experienced Quaker refugee worker and advisor to UNRRA, wrote of "Mother UNRRA" without whom the displaced would simply starve. ${ }^{54}$ "Most relief is for the helpless and is more a woman's job than a man's", she argued. 55 Mrs Murray seems a fine embodiment of such themes. ${ }^{56}$

In practice, women's status in UNRRA was not as obvious as Zinnemann suggests. UNRRA aimed to recruit an international staff "without discrimination on the grounds of sex, race, nationality or creed". 57 At the end of 1945 , it employed about 10,000 people, the great majority of them in Germany, Austria, and Italy. ${ }^{58}$ About 45 per cent of its staff were women. While women's contributions were valued, few of UNRRA's female employees were appointed to positions of authority: only a tiny minority were appointed as team directors, and the majority of UNRRA's female staff worked as welfare officers and assistants, nurses, or deputy directors.

54. Francesca M. Wilson, Aftermath (London, 1947), p. I74.

55. Idem, Advice to Relief Workers: Based on Personal Experience in the Field (London, 1945), p. 9.

56. William I. Hitchcock, The Bitter Road to Freedom: A New History of the Liberation of Europe (New York, 2008), p. 222.

57. UNRRA, Helping the People to Help Themselves: The Story of the United Nations Relief and Rebabilitation Administration (London, 1944), p. 19.

58. UNRRA, Fifty Facts about UNRRA (London, January 1946), unpaginated. 
In these roles, they had some opportunity to exercise initiatives and make decisions. Susan Pettiss records her delight about this point. "I could handle anything, or so I was beginning to believe. The team seemed to believe it too, and deferred to me constantly as a result. As a woman in a man's world, I was sensing a power hitherto unknown to me." 99

During the war established gender roles were challenged: some new opportunities opened up for women; the stigma attached to employment for married women evaporated. But there are some good reasons to be sceptical about the extent and depth of this emancipation. Jo Reilly, analysing women's contribution to the rehabilitation of the captives in Bergen-Belsen, points out that, despite the exceptional nature of the situation and the important tasks carried out by women, established gender roles were not challenged, and women were firmly kept to a confined, limited, subordinate sphere. ${ }^{6}$ A similar caution seems justified with reference to UNRRA: while the opportunities available to women within its structures were certainly "new" in the simplest sense of the word, and arguably important, fulfilling, and exciting, they rarely constituted any substantial challenge to the gendered hierarchies of mid-twentieth-century society.

Despite the changes of the wartime years, the experience of conflict ultimately reaffirmed the domestic ideal of breadwinner, homemaker, and child-rearer. In the USA, women returned to the home and this "norm" dominated American culture throughout the latter half of the decade. ${ }^{6 r}$ In this context, Mrs Murray is an interesting, slightly unusual, illustration of the wartime "new woman" who is married, has a career in an organization, but who will return shortly to her "normal" role in the USA.

The contrast between Mrs Murray and Mrs Malik is also significant. Mrs Murray keeps telling the children that she likes them and will not hurt them, but she never displays open, physical affection. Her concern and sympathy are kept in a professional form, and she maintains an emotional distance from the children in what appears to be a matronly representation of an efficient organisation. Her relationship with Karel offers a limited, but correct, institutional solution to his problems. UNRRA is seen to provide welfare and care on a temporary basis and acts like a guardian for the displaced children. However, Mrs Murray cannot offer a long-term substitute for Karel's family and homeland.

59. Pettiss and Taylor, After the Shooting Stopped, p. 62.

6o. Jo Reilly, "Cleaner, Carer and Occasional Dance Partner? Writing Women Back into the Liberation of Bergen-Belsen”, in Tony Kushner, David Cesarani, Jo Reilly, and Colin Richmond (eds), Belsen in History and Memory (London, 1997), pp. I49-г6г. The classic statement on this matter remains Margaret R. Higonnet and Patrice L.R. Higonnet, "The Double Helix", in Margaret Randolph Higonnet, Jane Jenson, Sonya Michel, and Margaret Collins Weitz (eds), Behind the Lines: Gender and the Two World Wars (New Haven, CT, 1987), pp. 31-47.

6r. Brinkley, "World War II and American Liberalism". 
On the other hand, Mrs Malik is a motherly figure to whom the children easily relate and show physical affection. Jarmila Novotna, who played Mrs Malik, was an attractive opera singer, and Zinnemann gave her the part on the condition that she wore minimal or no makeup at all, to ensure that she presented a "true" motherly look. (Pettiss noted Zinnemann's wish to present wholesome, natural women: he apologised to her for not casting her in the film explaining, "I can't have you in the movie. You are too glamorous." ${ }^{62}$ Mrs Malik is the epitome of self-sacrificing motherhood as she relentlessly searches for her child. She, rather than Mrs Murray, is the real homeland, and her relationship with Karel - representing the DP and the homeland - is the ideal solution where the family is reunited and the child returns home.

Mrs Murray is certainly an interesting fictionalization of UNRRA. What of the other elements of Zinnemann's depiction of UNRRA?

UNRRA camps certainly were as culturally and linguistically mixed as Zinnemann's film suggests: perhaps even more so. For example, Robert Collis, a Red Cross worker who worked with UNRRA in running the hospital established near the site of the Belsen concentration camp, remembers the DP mothers he met: "They protested in Polish; they wept in Hungarian; they howled in Roumanian and all spoke together in a sort of German." "33 Kathryn Hulmes records that her UNRRA team was made up of French driver, a Belgian messing officer, a Corsican doctor, a French director, a Dutch warehouse officer, a Norwegian welfare officer, and a Texan supply man: she was proud of their variety, claiming that together they formed "the United Nations in a test tube". ${ }^{64}$ It is probably quite typical of UNRRA's ideals that the officials who assisted Zinnemann commented, with pleasure, that his film constituted an example of "real international cooperation". ${ }^{65}$

But UNRRA's work rarely unfolded with the calm efficiency that Zinnemann suggests: UNRRA workers record the helplessness they felt in the face of the problems the DPs represented, their anger at the irregular incompetence with which supplies were distributed, and their frustration with regulations, whether imposed by the military authorities or devised by UNRRA itself. Hulmes records requesting 2,000 pairs of rubber gloves in order to carry out a medical inspection of her camp's DPs, and receiving $6 .^{66}$ Many UNRRA workers grew disillusioned. Zinnemann's images miss the anger and rivalries that could surge up

62. Pettiss and Taylor, After the Shooting Stopped, p. 203.

63. Robert Collis and Han Hogerzeil, Straight On (London, 1947), p. 93.

64. Kathryn Hulmes, The Wild Place (London [etc.], 1954), pp. 6, 9.

65. UNRRA Archives (New York), S-0425-0036-10, letter from William H. Wells to Zinnemann, 4 March I947.

66. Hulmes, Wild Place, p. 50. 
within their teams, and the improvised, haphazard, semi-legal methods they had to use in postwar Germany. He ignores the mutual antipathy between military and civilian authorities: it is worth remembering that Eisenhower, overall commander of the Allied forces that invaded Europe, only reluctantly accepted UNRRA's direction of DP camps in November I944, a year after its creation. ${ }^{67}$

Above all, Zinnemann makes the curious decision to concentrate on UNRRA's bureaucratic procedures: its screening of children. Once again, his images of UNRRA contrast sharply with those in Seeds of Destiny: the shorter documentary focuses on UNRRA's work in the distribution of food and medical supplies, and says nothing about DP camps or screening. One shot in The Search even focuses on an UNRRA screening form (I2). There is almost no depiction of UNRRA's work of "rehabilitation", just a single brief shot of three groups of children playing in a courtyard, one led by an UNRRA official ( 54$)$. Yet, once again, the records left by UNRRA workers speak at length of their daily initiatives to help, to guide, and to heal displaced persons. ${ }^{68}$ While the image of Mrs Murray as a female authority is memorable, imaginative and provocative, the film elides the more serious issue of the experience of the female displaced persons - a point which UNRRA did consider in some depth. ${ }^{69}$ The viewer's final impression of UNRRA, as depicted by The Search, is that it was a humanitarian bureaucracy, staffed by people processing children from railway stations, through offices and registration, on to trucks. "Rehabilitation" is reduced to the process of physically "returning" lost children to their true mothers.

With reference to Steve, we need to be careful not to replace Zinnemann's idealization with a dismissive stereotype. Zinnemann's images of the American military presence, however, are in sharp contrast to the neo-realist Germany Year Zero. Rossellini's film shows American GIs in nightclubs, where they pay for the company of women with cigarettes. One bartender tells a young German girl - in a reference to prostitution - that if she is prepared to spend more time with the soldiers, she would earn more than a few American cigarettes. The soldiers of The Search certainly do not resemble the overwhelming bulk of the historical evidence, which suggests a disturbing picture. William Hitchcock's recent work describes the "illicit sex economy" of American Germany, in which American soldiers bought sex from near-starving German women with food, cigarettes, chocolates, and soap; Petra Goedde describes the GIs' obsession with sex, and wonders whether

67. Hitchcock, Bitter Road to Freedom, p. 219.

68. See, amongst others, Pettis and Taylor, After the Shooting Stopped, and Hulmes, Wild Place. 69. For example, UNRRA, Welfare Guide to United Nations Nationals Displaced in Germany (London, I945), p. I4. 
they saw the conquest of the enemy women as part of their victory or as a form of revenge. ${ }^{70}$

This seedy reality is far removed from the Hollywood image of the strong, wholesome "he-man" projected through films of the period. Approximately I 6 million Americans had been in uniform during the war and soldiers overseas had taken on a larger than life, hero-type persona to the people at home. ${ }^{71}$ Examples from the period include Sergeant York (Hawks, I94I), which stars Gary Cooper in an adaptation of the real life of Sergeant Alvin York, the most decorated American soldier of World War I, who single-handedly saves his troop, captures a German officer, and returns home to marry and become a successful farmer. The Story of GI Joe (Wellman, 1944) tells the story of brave, selfless American infantrymen fighting and dying for their country during World War II and uses real American GIs as extras. Sahara (Korda, I943) stars Humphrey Bogart as tank commander, Joe Gunn, who shoots down a German plane and aids the capture of a German battalion, and which was hailed as "a mighty story of adventure, courage and glory". ${ }^{22}$

Quiet, hard-working, home-loving boys like Steve probably did exist among the crowd. Here, it is interesting that Zinnemann rejected the challenging radicalism of his first script, which was explicitly critical of the lifestyle of American soldiers, to produce a set of images which the home audience would find far more acceptable. ${ }^{73}$ Steve's sexless, homebased existence also rules out the exploration of another important theme: he has no German girlfriend, and The Search shows no contact whatsoever between Allied personnel and the German population. ${ }^{74}$

70. Hitchcock, Bitter Road to Freedom, pp. 196-197; Petra Goedde, GIs and Germans: Culture, Gender, and Foreign Relations, 1945-49 (New Haven, CT [etc.], 2003), pp. 83-84. In addition, Koshar states that 50 to 90 per cent of male soldiers went "fratting" with German women, and by 1946 there had been more than 2,000 marriages between American soldiers and German women; R. Koshar, German Travel Cultures: Leisure, Consumption and Culture (New York, 2000), p. I 89 .

71. A.M. Winkler, Home Front USA: America During World War II (Miami, FL, 2000), p. 3 I. 72. Information from the Internet Movie Database at page http://www.imdb.com/title/ ttoo36323/, accessed 25 April 2010.

73. This theme is considered in Etheridge, "In Search of Germans".

74. This could be in part due to the regulations surrounding the depiction of love and sexual relationships in Hollywood films which were set out in the Motion Picture Production Code, also known as the Hays Code after its creator Will H. Hays. Its recommendations governed the studios from the early i 930 s to the early i950s. The code stipulated that the sanctity of marriage and the home had to be upheld and references to forms of sexual relations such as adultery and prostitution could not be explicit, justified, or glamorized. Scenes of passion were not to be introduced unless essential to the plot and excessive and lustful kissing were to be avoided. Discussions relating to the Hays Code are in M. Bernstein (ed.), Controlling Hollywood: Censorship and Regulation in the Studio Era (London, 2000), pp. 76-90, and J. Nelmes, (ed.), An Introduction to Film Studies (London, 2003), pp. 4I-43. 
Steve, whose primary motivation is helping Karel, does not need a romantic interest; his personal life is not essential to the plot.

The Search's clean-cut images of the American military presence are very far from the critical and challenging script that Zinnemann originally planned. This was due, in part, to the constraints within which MGM was operating. In 1942 the Office of War Information (OWI) was created in America: it encouraged Hollywood to promote the war effort to a population removed from the fighting. The power of cinema in conveying ideas to a mass audience was realized and this policy continued after the end of the war as studios were advised to produce films that justified US involvement in the conflict and championed the occupation of Germany by US troops. Elmer Davis, director of the OWI, explained "the easiest way to inject propaganda ideas into most people's minds, is to let it go in through the medium of an entertainment picture when they do not realize they are being propagandized". ${ }^{75}$

Before World War II Hollywood had operated in a commercial market outside the constraints of state control, but after 1942 the OWI promoted "war films" and encouraged writers to dramatize and glamorize the ties between "characterizations [...] and the world struggle against fascism". ${ }^{6}$ This may explain one surprising contrast in the film: Mrs Murray's embodiment of a credible female authority is genuinely original, while the folksy friendship of Steve and Jerry merely perpetuates wartime clichés, functioning - in part - as extended comic relief against the serious dilemmas contained within the UNRRA scenes. ${ }^{77}$ If Zinnemann's aim really was to remedy Americans' "lack of comprehension of the extent of suffering abroad", then one can question whether these misleading, romanticized, folksy images, conforming to the policies advocated by the IWO and the studios, would have taught American audiences anything valuable. ${ }^{78}$

\section{THE CHILDREN OF THE SEARCH}

One element of the film which strengthens Mrs Murray's position in the film is Zinnemann's decision to represent the postwar DPs almost entirely through children. Would Mrs Murray have appeared so appropriate if she faced a crowd of male and female adult DPs?

The children often appear in crowd scenes, which present us with three images of childhood: the near-mute, brutalized figures of the first scenes; their potential as an anarchic force, demonstrated in their sudden mass

75. Quoted in Brinkley, "World War II and American Liberalism", pp. 74-75.

76. Ibid., p. 75 .

77. Curiously, in From Here to Eternity, Zinnemann did present a far more challenging picture of the social hierarchy at work within the US Army.

78. Zinnemann, "Different Perspective", p. I45. 
escape from UNRRA trucks; and the perfect examples of rehabilitation who happily stride into the trucks at the end of the film. These images represent, respectively, the problem, the danger, and the solution, and accurately reflect some of the concerns voiced by the newly "planning-minded" relief authorities and other contemporaries. The sight of the unchildlike child survivors disturbed many observers. Hirschmann watched similar children at Lampertheim DP camp. "These were not the eager, joyful faces of children; there was no open-eyed wonder, no spirit of play and spontaneity here. These were little, old people - quiet, sober, determined - as though they had skipped childhood and grown up overnight." ${ }^{\prime 9}$ His words could be applied to the children we see in the first scene of The Search.

There was also a particular concern about the development of "wild" children in the postwar cities: orphans, unsupervised by any authority. ${ }^{80}$ "It was not unusual to encounter or hear of numbers of ragged, malnourished children and youths wandering the roads and the countryside often begging and stealing, using their wits to survive", remembered Susan Pettiss, "These were children who chose not to enter the DP camps, for whatever reason." ${ }^{8 I}$ Some children had survived through their association with various types of resistance movements: here they had learnt "the use of force, subterfuge and deceit" in order to stay alive. ${ }^{82}$ Victor Gollancz, in his passionate and original work Darkest Germany, worried about a new generation being "poisoned and renazified". ${ }^{8}$ UNRRA and other agencies devised specific policies for treating children. Tracing agencies, attempting to reunite parents and children, were established by many authorities: one international tracing service held records on some 343,057 children between 1945 and $19566^{84}$

While these real issues represented by child survivors were undoubtedly important, the film's treatment of children is quite different, resembling other contemporary references to child experiences. Commentators often prized children: as innocents, they could be presented to audiences as "authentic witnesses [...] unencumbered by agendas". ${ }^{5}$ The Search's child-DPs do not form campaigning lobbies or complain about

79. Hirschmann, The Embers Still Burn, p. 161.

80. Goedde, GIs and Germans, pp. I30-I 32 .

8. Pettiss and Taylor, After the Shooting Stopped, p. I29.

82. A.M. Duchesne-Cripps, The Mental Outlook of the Displaced Persons as Seen Through Welfare Work in Displaced Persons Camps (Cambridge, 1955), p. 85.

83. Victor Gollancz, In Darkest Germany (London, 1947), p. 29. This fear was not entirely groundless: one of the last strategies developed by the Nazis consisted in the formation of guerrilla groups recruited from the Hitler Youth. See Perry Biddiscombe, Werwolf! The History of the National Socialist Guerrilla Movement, 1944-I946 (Cardiff, I998), pp. 60-85.

84. On this point, see the valuable analysis of Taha Zahra; "Lost Children", p. 45.

85. Boaz Cohen, "Representing the Experiences of Children in the Holocaust: Children's Survivor Testimonies Published in Fun Letsten Hurbn, Munich, I946-49", in A.J. Patt and 


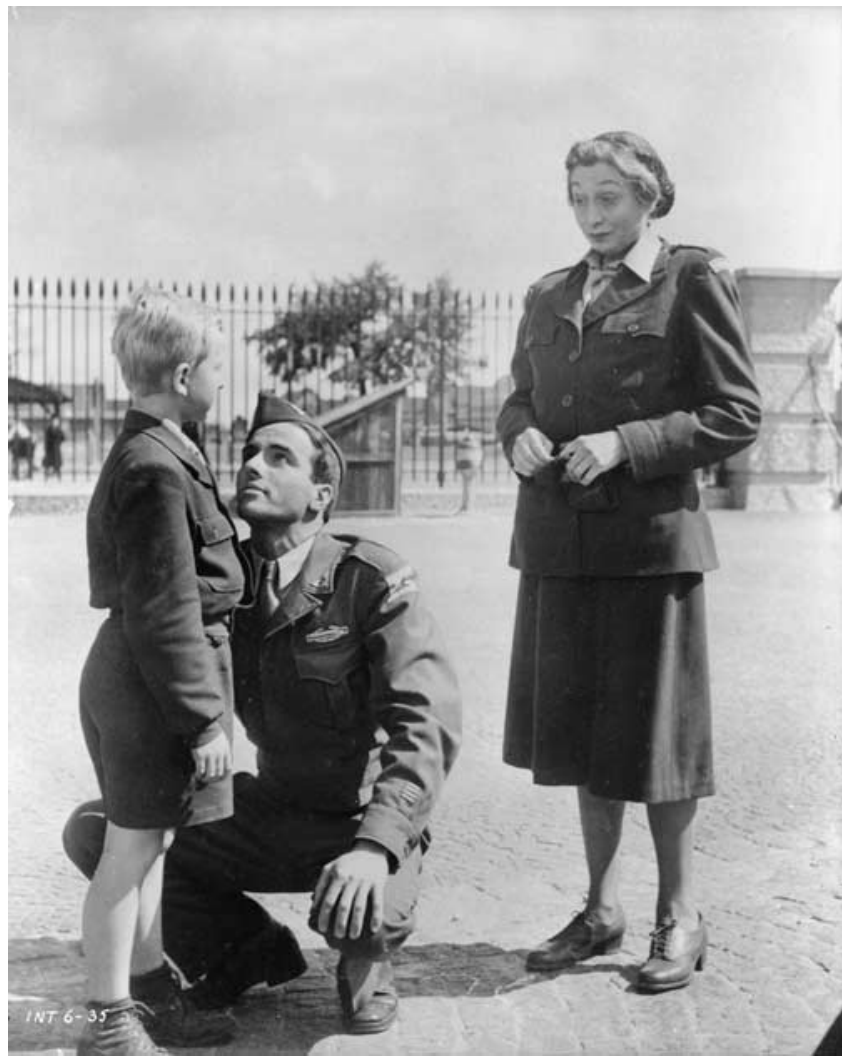

Figure 2. Mother, father, and child: Mrs Murray and Steve say goodbye to Karel as he looks at his real mother (off-camera).

Warner Bros. Used with permission.

their treatment; while the brief images of Karel sleeping rough are disturbing, they do not explicitly suggest crime or youth delinquency. If the DPs were portrayed as adults, a character such as the "false Karel" might suggest the serious issue of surviving Nazis going into hiding to avoid prosecution. ${ }^{86}$ In The Search, the episode ends peacefully with an avuncular

M. Berkowitz (eds), 'We are Here': New Approaches to Displaced Persons in Postwar Germany (Detroit, MI, 2010), pp. 74-97, 94.

86. This issue appeared in scores of films directly following the end of the war. Orson Welles's Oscar-nominated The Stranger (1946) follows an investigator from the War Crimes Commission as he attempts to track down a notorious Nazi, Kindler, who has settled in Connecticut. Kindler murders two people (one, another Nazi, and the other an innocent American woman and her dog) before he kills himself. Hitchcock's Notorious (1946) stars Ingrid Bergman as a woman whose German father has been convicted of treason against the US. FBI agent, Cary Grant, recruits her to spy on a group of Nazis who have adopted false identities and are living in America. 
British UNRRA worker saying "I'll take the boy upstairs, I want to be quite sure that nothing will happen to him." (0.33)

The portrayal of Karel suggests that the DPs are lost, separated from their loved ones, traumatized, innocent, powerless victims, in a foreign land, without identity, and searching for a solution. While Karel is able to kick against authority (literally), he is not able propose any practical solutions to his dilemmas. He has even lost the ability to speak after his experiences in Auschwitz and losing his mother. Karel is therefore a blank page on which Mrs Murray and Steve can write their scripts, and the extended scenes of his "rehabilitation" by Steve suggest some sort of rewriting of the social contract in order to found a new (American) civilization on the ruins of the old (Europe).

While staying with Steve, Karel is treated like a mascot, with a new name (Jimmy), a baseball bat, chewing gum, chocolate, and new clothes that look like a miniature version of Steve's uniform; he even cleans Steve's jeep, and gazes at magazine pictures of Abraham Lincoln, "a great man" (55) and New York, "the largest city in the United States" (56). ${ }^{87}$ But this process of Americanization is not unstoppable. After a moment of revelation, Karel remembers he has a mother and runs away. In the last scene, when he is reunited with his mother, he spontaneously remembers how to speak Czech. Here, there is a brief, but revealing, shot: Steve and Mrs Murray stand together, shoulder-to-shoulder, looking with pleasure as Karel runs to his mother (I.38). For a moment, they look like proud mother and father: unusual parents, certainly, whose greatest achievement is giving away their child to Mrs Malik, but nonetheless happy and satisfied with their success.

There are many problems inherent in Zinnemann's images. In fact, the children he has chosen - approximately five- to fifteen-year olds - were precisely the intensely vulnerable age group that was less likely to survive Nazi terror and the conflicts of the war. ${ }^{88}$ Following the DPs' liberation and subsequent recovery, the birth rate in some camps soared, but these babies do not feature in The Search. ${ }^{89}$ While the narrative skirts round the issue of juvenile delinquency, it never faces the other forms of criminality which hostile critics claimed were rife among the displaced persons: theft, murder, illegal abortions, revenge attacks, and drunkenness. ${ }^{90}$ Instead, Zinnemann's

87. These images do resemble the actual practices of the allied armies, in which soldiers would adopt lost children as mascots for their units. See Pettiss and Taylor, After the Shooting Stopped, p. II 8 .

88. See Zahra, "Lost Children".

89. See Anita Grossmann, "Victims, Villains and Survivors: Gendered Perceptions and SelfPerceptions of Jewish Displaced Persons in Occupied Postwar Germany", Journal of the History of Sexuality, I I (2002), pp. 291-318.

90. Hitchcock's Bitter Road to Freedom provides a useful survey of these issues. 
film is determinedly optimistic and positive. One analysis of British accounts of the liberation of Belsen has observed that "when survivors are represented, it is often to refer back to the reflected decency of the liberators" ${ }^{9 \mathrm{I}}$ The Search seems to have been constructed around precisely these priorities: the innocent, mostly harmless, blond, blue-eyed Karel is rehabilitated by the joint efforts of the unmistakably decent Steve and Mrs Murray.

The composite picture of child displaced persons in the film seems to have been constructed to make them as unthreatening as possible to an American audience. They are apolitical, grateful, and incapable of political protest. Lastly, their cultural and ethnic identities prove to be fully compatible with the needs of American foreign policy: while admiring the USA, the DPs in The Search have no strong wish to emigrate there. Karel will return to Czechoslovakia with his true mother, and the orphaned Jewish children will "return" to Palestine under the guidance of efficient, humanitarian Zionist leadership. Any British objections to such movements can be swiftly rejected as mere late-imperialist pride, while Arab opinion is not even considered.

\section{ZIONISM AND IDENTITY}

Is The Search a Holocaust movie, as argued by Lawrence Baron? There is some reason to challenge this categorization. Firstly, Zinnemann continually holds back from making issues explicit to his audience. The word "Nazi" is never used in the film, although "SS" can be heard once. The word "Jewish" is only used twice, the word "Jew" never. The representation of the death camps is reduced to a single shot of a fence. Much of the Jewish presence on the screen is left implicit: for example, as the rehabilitated young children shout "Shalom!", one can spot that the words "six million dead" in Hebrew on the blackboard behind them, and a picture of Herzl on the back wall. Similarly, when we see the film's opening shots of a heap of children lying motionless in a goods wagon, it is hard for us not to think of the trains carrying Jews to the death camps. ${ }^{92}$ Would American audiences have spotted these clues in 1948 ?93 In place of genuinely informative or educational images, Zinnemann merely hints that something dreadful has happened: a happy family has been separated, a father and a daughter have died, a child has lost his ability to speak.

91. Tony Kushner, David Cesarani, Jo Reilly, and Colin Richmond, “Approaching Belsen: An Introduction", in idem, Belsen in History and Memory, pp. 3-36, I 3 .

92. Steve Reich's sombre composition "Different Trains" (I988) suggests something inherently sinister about trains themselves in this period.

93. Baron argues that full American public awareness of the Jewish ordeal only developed during the late i 950 s when the term "Holocaust" became synonymous with Hitler's eradication of the Jews; see Baron, "First Wave of American 'Holocaust' Films". 
These impressions of some recent disaster are magnified, but not clarified, by the striking external shots of the wrecked cityscape. ${ }^{94}$

Zinnemann was born into an Austrian-Jewish family in 1907, and immigrated to the USA in 1929. He experienced anti-Semitism in Austria, later recording that "discrimination had been a part of life since time immemorial [...]. A Jew was an outsider, a threat to a country's culture." 95 He lost both his parents in the Holocaust. ${ }^{96}$ His research in Germany concentrated on Jewish experiences, but by casting the Jewish children of The Search as secondary characters, he avoids exploring the Nazi persecution of the Jews in any depth, eliding the true horrors of the Holocaust.

Such reactions were typical of the time: many experienced observers were unsure about how they should understand or represent the Holocaust. ${ }^{97}$ There was a widespread fear by some genuinely liberal-minded people that drawing attention to Jewish suffering might backfire: it would allow antiSemites to argue that the war had been fought for the Jews. ${ }^{98}$ Even apparently simple decisions such as whether to classify someone as a "German Jew" or a "Jewish German" presented the new authorities with unexpected dilemmas. ${ }^{99}$ Notoriously, the British authorities in Germany consistently attempted to deny any national status to persons classified as Jews, and frequently newly constructed Jewish organisations would bitterly claim that the specific horror of their experience was still being underestimated or ignored. ${ }^{100}$ It often appeared, they argued, as if post-Holocaust Jews were being merged into an undifferentiated spectrum of human suffering.

UNRRA agencies were often willing to allow Zionist groups to make use of their facilities, to the point where one could speak of a type of "passive cooperation" developing between the two. On the other hand, individual UNRRA workers were frequently sceptical or critical of

94. Here, Zinnemann has employed a classic neo-realist technique. In Rossellini’s Journey to Italy (1954) we see him mirror the breakdown of a marriage against a ruined, rubble-filled landscape.

95. Zinnemann, A Life in The Movies, p. II.

96. Ibid., p. 55 .

97. See Hitchcock, Bitter Road to Freedom, pp. 310-332; Angelika Königseder and Juliane Wetzel, Waiting for Hope: Jewish Displaced Persons in Post-World War II Germany, John A. Broadwin (transl.) (Evanston, IL, 200I), pp. 2I-28; and Martin Cohen, "Culture and Remembrance; Jewish Ambivalence and Antipathy to the History of Resistance", in R. Rohrlich (ed.), Resisting the Holocaust (Oxford, I998), pp. 19-38.

98. For a discussion of this theme in a British context, see Tony Kushner, "From 'This Belsen Business' to 'Shoah Business': History, Memory and Heritage, I945-2005”, in Suzanne Bardgett and David Cesarani (eds), Belsen 1945: New Historical Perspectives (London, 2006), pp. I89-216.

99. This example is analysed in some detail in Frank Caestecker, "The Reintegration of Jewish Survivors into Belgian Society, 1943-47", in Bankier, The Jews Are Coming Back, pp. 72-107. Iо०. See Arieh J. Kochavi, Post-Holocaust Politics: Britain, the United States and Jewish Refugees, I945-48 (Chapel Hill, NC, 200I), particularly pp. 37-43. 
Zionist initiatives. Pettiss, for example, was disappointed to see separate UNRRA camps for Poles, Ukrainians, Jews, and west Europeans: she had been hoping that the shattered populations of the postwar world would immediately form a single, united community. ${ }^{\text {IOI }}$ Elsewhere, UNRRA reports described Jewish survivors as "infantile, deceitful, demanding, revengeful, jealous and constantly fighting among themselves". ${ }^{\text {IO2 }}$

While exact figures about the different groups within the mass of DPs will never be established, it is, however, absolutely clear that Jewish survivors were always a minority. According to one author, in spring 1947 there were approximately 250,000 Jews held in the relief camps: about a quarter of the million DPs in Germany. ${ }^{103}$ The Search, however, leaves viewers with the impression that the overwhelming majority of DPs were Jewish. In the final analysis, Zinnemann's highlighting of the Jewish experiences is as misleading as other contemporary arguments that there had been nothing specific about the Jewish experience, for his film still confuses the particular persecution suffered by Jews with the more general experience of Nazi terror.

The Search promotes the idea of Palestine as an appropriate homeland for the Jews and one of the final scenes of the film shows a group of Jewish children preparing for the long voyage "home". Mrs Murray describes the children going to Palestine as "close knit [...] like a family" (55). While Karel, a non-Jew, is considered for adoption into the US, the offer is not extended to the Jewish children, or even considered for them. Their only possible home is Palestine. Zinnemann's film does not challenge American resistance to immigration from Europe, and once again the clout of MGM and its awareness of public opinion must be considered.

The issue of the Holocaust was an awkward one for a film director. America's well-established Jewish community had been radicalized during the war; immigration in general and Jewish immigrants in particular had been charged political issues since the ig2os (if not before), yet there is evidence that attitudes were changing during the months in which The Search was produced. Winkler notes that by 1942 the US had only accepted I 50,000 European refugees - mostly Jewish - and that several hundred thousand more Jews could have been saved if Roosevelt and his policy-makers had acted on authenticated evidence of Nazi atrocities that they had received. ${ }^{\mathrm{I}} 4$ The issue of immigration remained contentious at

I0I. Pettiss and Taylor, After the Shooting Stopped, pp. 62, i 25.

102. Eva Kolinsky, After the Holocaust: Jewish Survivors in Germany after 1945 (London, 2004), p. 92.

I03. Georges Bensoussan, Israel, le sionisme et la destruction des Juifs d'Europe (Paris, 2008), p. 72. Kathryn Hulmes estimates that in 1947-1948 less than one-fifth of the DPs in the American zone were Jewish, and complains about the amount of publicity given to this minority; Hulmes, The Wild Place, p. 179.

104. Winkler, Home Front USA, pp. 84-85. 
the end of the war, with a 1945 Gallup poll concluding that 52 per cent of Americans surveyed favoured a decrease or suspension of immigration, 32 per cent favoured the status quo, and just 5 per cent supported plans to increase immigration levels. ${ }^{105}$ Later that year Truman extended 40,000 preferential visas to the US for Holocaust survivors and urged Britain to open Palestine to Jewish refugees. ${ }^{\text {Io6 }}$

As evidence of the horrors endured by Jews in Nazi concentration camps became better-known, American public opinion moved to support Truman and his call for Jewish immigration to Palestine. In 194536 per cent of Americans surveyed supported the creation of a Jewish state in Palestine. By 1945 the figure had risen to 42 per cent, and in $1947-$ the year Zinnemann began making The Search - the figure stood at 65 per cent. ${ }^{107}$ The Search seems to represent a type of compromise: in a strong, but indirect, manner it voices concern for the Jewish experience, but never suggests that post-Holocaust Jews should be allowed to emigrate to the USA. Instead, like other American film-makers, Zinnemann depicted Palestine as a solution to the Jewish "problem", and suggested that Zionism was a progressive cause that would empower Jews and help them overcome the terrible ordeal they had endured. ${ }^{108}$

Zinnemann's constant focus on child DPs functions to depoliticize the issue: rather a political cause, Zionism merely seems like a type of social maternity extended to Europe's lost children. In the final scenes of The Search we see evidence of empowerment for the Jewish children previously described as "robots" and victims of slave labour - who are depicted as bright, happy, and now in possession of a more certain, positive future. Interestingly, this depiction of American-UNRRAZionist cooperation could be seen as the one bridge to whose construction Steve does successfully contribute.

For these reasons, The Search can only be classified as a "Holocaust film" in the loosest possible sense: it does face some of the issues raised by the Holocaust, but only indirectly, clumsily and euphemistically. The focus of the film seems, instead, to be rehabilitation and relief agencies.

\section{CONCLUSION}

Why The Search was such a success in 1948 is a complex question to which only speculative answers can be offered. The release of The Search coincided with the movement toward greater realism in cinema that

I05. D.J. Tichenor, Dividing Lines: The Politics of Immigration Control in America (Oxford: 2002), p. 183 .

106. Ibid., p. 182.

107. Baron, "First Wave of American 'Holocaust' Films".

108. Ibid. 
followed the end of World War II. During the war audiences had been exposed to a new "documentary realism" contained in newsreel footage and public information films about the conflict and now they demanded that this kind of naturalism in other forms of postwar cinema. ${ }^{109}$ Zinnemann had had experience of producing documentaries at MGM and was keen to share his passion for realistic cinema. By immersing the audience in the postwar German environment, and using extensive external shots of rubble and ruined landscapes, he successfully provides a "feel" of what Europe was like after 1945. In this sense the climate was "right" for The Search and its documentary-style filming, set on location, to be successful.

The skill of Zinnemann as a director must also be noted. He was able to convey a depth of emotion through his use of mise-en-scène, ${ }^{\text {IIO }}$ that not only enhanced the film's believability but encouraged the audience to associate with, and feel sympathy for, the characters. For example, in the emotional moment when Steve (mistakenly) tells Karel that his mother is dead, Zinnemann places the scene not in urban rubble, the UNRRA centre, or the requisitioned home where the rest of the action has taken place, but in a serene setting of trees, flowers, and a flowing river. The setting is a softening consolation for the dreadful pain of Karel's discovery that his mother is apparently dead.

The emotion created by such scenes leads to an empathy with the characters which is ultimately reinforced by the talent of the actors themselves: the fact that this film launched the successful career of Montgomery Clift is testament to his ability to portray the likeable Steve effectively. Many of the audience would have had a family member who served during the war, or was based in occupied Germany after the war ended, so for them the reassurance that their soldiers functioned as a moral force creating a better world was welcome. The performance of all the actors - both professional and non-professional - in the film is believable and the direction of Zinnemann ensures that sentimentality and "over-acting" is kept to a minimum.

The Search is a valuable film that provides insight into the issues such as displaced persons, immigration, and the various solutions offered by US and European authorities to the problems faced in rehabilitating postwar Germany. Zinnemann's political stance is hard to ascertain as, despite his own experiences of anti-Semitism, he declines to explore the Holocaust explicitly through the Jewish characters in the film. Whether this was due to the constraints placed on the script by MGM or his desire to "educate without shocking" a naive American audience is unclear.

109. G.D. Phillips, Exiles in Hollywood: Major European Film Directors in America (Bethlehem, PA [etc.], I998), p. I49.

I Io. See note 23, relating to James Monaco's definition of mise-en-scène. 
Whilst suggesting the problem of displaced persons defies easy resolution, the film offers a simple, logical - if contradictory - ending in the unlikely reunification of mother and son. The idea of Palestine as a homeland for the Jews is also suggested with convincing ease, as is the proposition that, despite relief being vital in assisting the immediate needs of DPs, it should be provided on a temporary basis only. With both the character of Steve, an American soldier, and Mrs Murray, the American representative for UNRRA, US foreign policy is explored and assigned the position of temporary but necessary care-giver. The Search presents a positive image of the role that UNRRA played in assisting, reuniting, and re-homing displaced persons. Audiences may well have left the film feeling both educated and pleased that America was doing good in Germany.

Despite his protests that he sought to create characters of conscience and to make films that had a clear moral message, it must be remembered that Zinnemann was working within the profit-driven Hollywood studio system. Perhaps The Search achieved Zinnemann's goal of educating the masses and in turn generating revenue through donations to war-relief funds, but if so this education was limited. Was Hollywood cinema the right place to educate a postwar American audience already suffering human losses of their own about atrocities in a foreign land? The Search suggests that, in reality, commercial cinema only had a limited educative potential. ${ }^{\text {II }}$

In the last analysis, The Search is a conservative film. The wrongs of Nazism are righted. The metaphor of parent and child structures it from beginning to end: democratic participatory values are never evoked as solutions. The great principles which guide the characters are biological and national, and the American presence in Europe is portrayed as aiding this bio-national reconstruction of national communities on their correct basis. If there is a challenge to the audience in the film, it is in its lesson that new types of "soft" power will be needed to perform this role: while Flying Fortresses and Sherman tanks could destroy Nazi military power and devastate German cities, parental figures like Steve and Mrs Murray would be needed for the equally demanding task of reconstruction.

I I I. Orson Welles also believed in the use of cinema as an educative tool. In The Stranger (1946) he used actual newsreel footage taken during the liberation of several of the concentration camps. See the interview published online at Old Hollywood, accessible via page http://oldhollywood.tumblr.com/post/2724779304/the-stranger-1946-dir-orson-welles, accessed Is February 20 I. 


\section{APPENDIX: THE THREE FACES OF UNRRA}

The United Nations Relief and Rehabilitation Administration was created in November 1943. It was a prominent example of an attempt to learn lessons from World War I: specifically, to avoid the epidemics and famines that killed so many in the years after I9I 8. Very quickly UNRRA became a repository for some of the most optimistic elements among the Allies, attracting people who believed that the Allied victory would create a new, better world. It was disbanded, in stages, in 1947-1948. In its approximately four years of existence, it achieved some great successes and probably deserves some further study by historians. There are three possible avenues of historical research.

Arguably, the fact that the postwar world was not ravaged by epidemics can be attributed to UNRRA's success in sending food, clothing, and medical supplies around the world. By June 1947 it had spent US\$3.5 billion, mostly on these forms of practical, international aid. ${ }^{12}$ Perhaps inevitably, this programme carried with it problems. Graham Greene's The Third Man refers once to UNRRA's successor - the International Refugee Organization - but, nonetheless, the book can be read as an UNRRA novel. The weary comment by one of the work's characters - "Everybody's in a racket" - sums up the dilemma of UNRRA's programme. ${ }^{\mathrm{II} 3}$ In a context of a flourishing black market and irregular, battered economies, it was impossible for UNRRA officials to maintain the economic probity of their operations, and they quickly acquired a reputation for corruption.

A second aspect of UNRRA's work was the relief and care for the displaced persons. To some extent, one can see a continuity of policy: just as famine could be avoided by shunting foodstuffs to the needy parts of the world, so social and cultural breakdown could be avoided by shunting displaced persons back to their right nations. UNRRA ran camps for DPs in Europe and the Middle East, and encouraged them to "return". In practice, it proved to be more difficult than expected to "re-place" a large minority of DPs. This aspect of UNRRA's work has attracted more interest from historians, and most studies of the fate of post-Holocaust Jews notes UNRRA's role in providing assistance and relief.

However, existing studies tend to concentrate on UNRRA as an example of social policy in practice. There remains a third aspect to UNRRA's work still to be studied: the social history of their relations with the DPs they aimed to assist. This presents a more challenging set of issues, which we hope to explore in another work. ${ }^{\mathrm{I} 4}$

I 12. Richard Ford, UNRRA in Europe, 1945-1947 (London, 1947), p. 9.

I 13. Graham Greene, The Third Man (London, 2005 [1955]), p. 32.

I 14. See Sharif Gemie, Fiona Reid, and Laure Humbert (with Louise Rees), Outcast Europe: Refugees and Relief Workers in an Era of Total War, 1936-48 (London, forthcoming, 201 I-2012). 